\title{
The protective effect of propolis against aluminum chloride-induced hepatorenal toxicity in albino rats
}

\author{
Hanan A. Okail', Ahmed S. Ibrahim and Amira H. Badr
}

\begin{abstract}
Background: The use of natural products is an essential way to new pharmaceutical leads for the discovery and development of new drugs to treat diseases. Propolis (Pro) is a natural resinous product produced by honey bees. It has a strong cytoprotective effect against various exogenous toxic agents. The current study was designed to evaluate the possible protective effect of propolis against the toxicity of aluminum chloride $\left(\mathrm{AlCl}_{3}\right)$ on hepatorenal structure and function in male white albino rats.

Methods: Thirty mature males of albino rat, Rattus rattus, weighing about 80-90g were divided into five groups contained 6 rats each. The first group acts as a control (received only saline solution); the second group (Al) had given orally $40 \mathrm{mg} / \mathrm{kg}$ b.w. of $\mathrm{AlCl}_{3}$, the third group (Pro) had administrated orally $150 \mathrm{mg} / \mathrm{kg} \mathrm{b.w}$. of propolis and the fourth group (Al+Pro) had given $40 \mathrm{mg} / \mathrm{kg} \mathrm{b.w}$. of $\mathrm{AlCl}_{3}$ in the morning and $150 \mathrm{mg} / \mathrm{kg} \mathrm{b.w}$. of propolis in the evening. These four groups had given the treatments for two months. The fifth group (Al-Pro) had given $40 \mathrm{mg} / \mathrm{kg}$ b.w. of $\mathrm{AlCl}_{3}$ chloride for one month then had given $40 \mathrm{mg} / \mathrm{kg}$ b.w. of $\mathrm{AlCl}_{3}$ combined with $150 \mathrm{mg} / \mathrm{kg}$ b.w. of propolis for another month.
\end{abstract}

Results: The $\mathrm{AlCl}_{3}$-treated group showed a significant increase in the activities of aspartate transaminase (AST), alanine transaminase (ALT), alkaline phosphatase (ALP), acid phosphatase (AP), and lactate dehydrogenase (LDH) in the plasma. Also, glucose, total protein, albumin, creatinine, uric acid, urea, cholesterol, and triglycerides in the plasma were significantly increased. The histological examination for the liver and kidney sections revealed marked histopathological alternations. The treatment with propolis combined with $\mathrm{AlCl}_{3}$ improved the previous mentioned biochemical and histological alterations induced by $\mathrm{AlCl}$.

Conclusion: It can be concluded that the combination of propolis with $\mathrm{AlCl}_{3}$ alleviated the toxic effects of $\mathrm{AlCl}_{3}$. The propolis has protective influences on the hepatorenal structure and function and could be able to resist $\mathrm{AlCl}_{3}$ intoxication.

Keywords: Aluminum chloride, Propolis, Histopathology, Liver function, Kidney function

\section{Background}

Several environmental elements, industrial chemicals, and food additives have been implicated as triggering adverse effects. Aluminum (Al) is the most abundant metal in the environment, where it constitutes $8.13 \%$ in earth's crust. It is used in daily life as constituent of

\footnotetext{
*Correspondence: hananokail@yahoo.com

Department of Zoology, Faculty of Science, Sohag University, Sohag, Egypt
}

cooking utensils, medicines, cosmetics, and food additives. Besides, it can be found in manufactured food especially tea, salt, spices, herbs, yellow cheese, and corn. In addition, aluminum salts are used in water purification (Kumar, Bal, \& Gill, 2009). Aluminum has toxic effect for both human and animals. It enters to the body through respiratory and gastrointestinal tracts and accumulates in different tissues such as the liver, kidneys, brain, and heart (Reiter, Tan, Terron, Flores, \& Czarnocki, 2007). However, aluminum

\section{Springer Open}

(ㅇ The Author(s). 2020 Open Access This article is licensed under a Creative Commons Attribution 4.0 International License, which permits use, sharing, adaptation, distribution and reproduction in any medium or format, as long as you give appropriate credit to the original author(s) and the source, provide a link to the Creative Commons licence, and indicate if changes were made. The images or other third party material in this article are included in the article's Creative Commons licence, unless indicated otherwise in a credit line to the material. If material is not included in the article's Creative Commons licence and your intended use is not permitted by statutory regulation or exceeds the permitted use, you will need to obtain permission directly from the copyright holder. To view a copy of this licence, visit http://creativecommons.org/licenses/by/4.0/. 
caused nephrotoxicity (Kutlubay et al., 2007), hepatotoxicity (Bhasin, Singla, \& Dhawan, 2014), hematotoxicity (Turgut, Bor-Kucukatay, Emmungil, Atsak, \& Turgut, 2007), and neurotoxicity (Stevanović et al., 2009). Moreover, Al compounds may bind to DNA and RNA and cause inhibition in such enzymes as acid and alkaline phosphatases, hexokinase, phosphodiesterase, and phosphooxidase (Ochmański \& Barabasz, 2000). In addition, Al induced alternation in biochemical parameters, lipid peroxidation, and reduction of the antioxidant enzymes activities in plasma and different tissues of male rats and rabbits (Newairy, Salama, Hussien, \& Yousef, 2009; TÜRKEZ, GEYİKOĞLU, \& Colak, 2011; Yousef, 2004). It has been reported that $\mathrm{Al}$ caused lipid peroxidation in the kidney and liver of male rats (El-Demerdash, 2004).

The use of natural products is an important way to new pharmaceutical leads for the discovery and development of new drugs for treating diseases (Watanabe, Amarante, Conti, \& Sforcin, 2011). Propolis, bee glue, is a natural resinous product produced by honey bees from substances gathered from exudates and buds of plants. It has a strong cytoprotective effect against various exogenous harmful and toxic agents (Rizk, Zaki, \& Mina, 2014). The chemical compositions of propolis are beneficial to bees and also have an important pharmacological value as a natural mixture (Oršolić, 2010). Currently, propolis is used in medical and dental sciences based on its chemical composition and its therapeutic properties (Elmenoufy, 2012). Essentially, it is widely used as a component in cosmetic and pharmaceutical products such as facial and body creams, ointments and lotions, antiacne creams, and several formulations for oral hygiene (Castaldo \& Capasso, 2002).

The general chemical structure of propolis is composed of $50 \%$ resin, $30 \%$ wax, $10 \%$ essential oils, $5 \%$ pollen, and $5 \%$ various organic compounds including flavonoids, minerals, terpenes, and organic compounds like phenolic acids (caffeic and cinnamic acid) or their esters, fatty acids, aromatic aldehydes and alcohols, stilbenes, and -steroids (Simões et al., 2004). The biological properties of propolis have been used in folk medicine as antiamoebic, antifungal, antibacterial, antipyretic, anti-proliferative and antiinflammatory (Banskota et al., 2002; Farooqui and Farooqui, 2010) and immuno-modulatory (Ivanovska, Dimov, Pavlova, Bankova, \& Popov, 1995); antioxidant, immune-stimulating, and non- toxic natures (Cole et al., 2010). Many researchers (Andrade, da Silva Filho, Cunha, Nanayakkara, \& Bastos, 2008; Ibrahim, Khalifa, Saleh, \& Tammam, 2019; Peña, 2008) illustrated that propolis works as a hepatoprotective substance. Previous studies also reporting that propolis have ameliorative role against the hepatic and renal damage caused by the oxidative stress damage (Wagh, 2013). Recent researchers reported that propolis has a cytoprotective role due to its antioxidant property, which attributed to its ingredients from phenol compounds (ElGuendouz et al., 2017; Machado et al., 2016). Also, many studies have demonstrated potential positive effects of propolis on glucose metabolism in human (Afsharpour, Hashemipour, Khadem-Haghighian, \& Koushan, 2017), and experimental models of diabetic rats ( El Araby, Ahmed, \& Zahkouk, 2017). Therefore, the present study was aimed to investigate the protective effect of propolis against $\mathrm{AlCl}_{3}$ toxicity on hepatorenal dysfunction and structure.

\section{Methods \\ Experimental animals}

Males of albino rats, Rattus rattus, were obtained from the animal house of Assiut University, Egypt. For this study, animals were reserved in cages at room temperature for a period of 2 weeks to reach their optimal conditions of weight and maturity. All animal experimental protocols were approved by the Committee of Scientific Ethics at Sohag University and were carried out in accordance with its guidelines for animal use.

\section{Drugs}

Aluminum chloride $\left(\mathrm{AlCl}_{3}\right)$ (Merk), propolis was obtained as crude from Faculty of Agriculture, Sohag University, Egypt. A water-soluble derivative of propolis (WSDP) was prepared according to a method described by Orsolic, Sver, Terzic, and Basic (2005). Briefly, it was extracted with $96 \%$ ethanol, and then, extract was filtered and left to dry. The resultant resinous product was added to a stirred solution of $8 \%$ L-lysine (sigma) and freeze-dried to yield WSDP (a yellow-brownish powder). WSDP was stored at $-20{ }^{\circ} \mathrm{C}$ until use. The WSDP was dissolved in distilled water and was given to rat orally at a dose of $150 \mathrm{mg} / \mathrm{kg}$ b.w. (Orsolic et al., 2005).

\section{Animal grouping}

Thirty mature males of albino rat, Rattus rattus, weighing about 80-90 g were divided into five groups contained 6 rats each. The first group acts as a control (received only saline solution); the second group ( $\mathrm{Al}$ ) had given orally 40 $\mathrm{mg} / \mathrm{kg}$ b.w. of $\mathrm{AlCl}_{3}$ It has been reported that the $\mathrm{LD}_{50}$ of $\mathrm{AlCl}_{3}$ was $400 \mathrm{mg} / \mathrm{kg}$ b.w. (Krasovskiī, Vasukovich, \& Chariev, 1979; Yousef, 2004). The third group (Pro) had administrated orally $150 \mathrm{mg} / \mathrm{kg}$ b.w. of propolis, and the fourth group ( $\mathrm{Al}+$ Pro) had given $40 \mathrm{mg} / \mathrm{kg}$ b.w. of $\mathrm{AlCl}_{3}$ in the morning and $150 \mathrm{mg} / \mathrm{kg} \mathrm{b.w}$. of propolis in the evening. These four groups had given the treatments for 2 months. The fifth group (Al - Pro) had given $40 \mathrm{mg} / \mathrm{kg}$ b.w. of $\mathrm{AlCl}_{3}$ chloride for 1 month then had given $40 \mathrm{mg} /$ $\mathrm{kg}$ b.w. of $\mathrm{AlCl}_{3}$ combined with $150 \mathrm{mg} / \mathrm{kg}$ b.w. of propolis for another month. 


\section{Biochemical analysis}

After 2 months of treatments, the animals of each group were scarified, and the collected blood was putted in a tube containing anticoagulant. It was centrifuged at $3000 \mathrm{rpm}$ for $20 \mathrm{~min}$ to obtain plasma. The obtained plasma was stored frozen at $-20^{\circ} \mathrm{C}$ until use.

Alanine aminotransferase (ALT) and aspartate aminotransferase (AST) were determined as described by Reitman \& Frankel, 1957. Alkaline phosphatase (ALP) activity was measured by the method of Bablok, Passing, Bender, and Schneider (1988). Acid phosphatase (AP) activity was measured spectrophotometry at $405 \mathrm{~nm}$ by Moss, 1984 . Lactate dehydrogenase (LDH) was performed as described by Cabaud, Wróblewski, ok, and Ruggiero (1958). Plasma glucose level was measured as described by Hyvarinen and Nikkila (1962). The estimation of total protein was carried out by the method of Henry (1964). The method of Doumas and Biggs (1976) was used for the estimation of albumin. Plasma urea, uric acid, and creatinine concentrations were measured by the methods of Patton and Crouch (1977), Barham and Trinder (1972), and Weissman, Pileggi, Henry, Cannon, and Winkelman (1974), respectively. The estimation of cholesterol in plasma was carried out according to the method of Watson (1960). The estimation of triglycerides was carried out according to the method of Bablok et al. (1988).

\section{Histological examination}

After 2 months of treatments, the liver and kidney of different animal groups were prepared for histological examination through the routine technique according to the method of Bancroft and Gamble (2008) and stained with couple stain haematoxalin $(\mathrm{H})$ and eosin $(\mathrm{E})$. The slides were examined and photographed as required.

\section{Statistical analysis}

Results were presented as means $\pm \mathrm{SE}$. The student's $t$ test was used for comparison of different experimental animal groups and control ones, and the results were considered significant at $P<0.05$.

\section{Results}

\section{Biochemical results}

The influences of $\mathrm{AlCl}_{3}$ ( $40 \mathrm{mg} / \mathrm{kg}$ b.w.), propolis $(150 \mathrm{mg} /$ $\mathrm{kg}$ b.w.), propolis combined with $\mathrm{AlCl}_{3}$, and the administration of $\mathrm{AlCl}_{3}$ for 1 month followed by administration of $\mathrm{AlCl}_{3}$ combined with propolis for another month on the plasma level of alanine aminotransferase (ALT), aspartate aminotransferase (AST), alkaline phosphatase (ALP), acid phosphatase (AP), and lactate dehydrogenase (LDH) in the albino rats were evaluated. The $\mathrm{AlCl}_{3}$ treatment led to a highly significant increase $(P<0.001)$ in plasma level of ALT, AST, ALP, AP, and LDH relative to that of control. Propolis and $\mathrm{AlCl}_{3}$ combined with propolis groups had nonsignificant effect $(P>0.05)$ on the plasma level of the previous mention parameters relative to that of the control. The administration of $\mathrm{AlCl}_{3}$ for month followed by administration of $\mathrm{AlCl}_{3}$ combined with >propolis for another month led to non-significant effect $(P>0.05)$ on the plasma level of AST and LDH, and a significant increase $(P>0.05)$ on the plasma level of ALT, ALP, and AP relative to that of control. In comparison with the effect of $\mathrm{AlCl}_{3}$, the treatments with propolis, $\mathrm{AlCl}_{3}$ combined with propolis, and the administration of $\mathrm{AlCl}_{3}$ for month and combined with propolis for another month led to highly significant decrease $(P<0.001)$ in the levels of ALT, AST, ALP, AP, and LDH in the plasma (Table 1, Fig. 1).

Table 1 The effect of $\mathrm{AlCl}_{3}$ chloride (40 mg/kg b.w.), propolis (150 mg/kg b.w.), $\mathrm{AlCl}_{3}$ Combined with propolis and $\mathrm{AlC1} 1_{3}$ Choloride for one month followed by administration of $\mathrm{AlCl}_{3}$ combined with propolis for another month on the biochemical parameters in plasma

\begin{tabular}{llllll}
\hline Treatment & Control & Al & Pro & Al+Pro & Al-Pro \\
\hline ALT $(\mathrm{U} / \mathrm{l})$ & $18.49 \pm 1.34$ & $35.80 \pm 1.81^{\mathrm{a}}$ & $19.61 \pm 1.85^{\mathrm{b}}$ & $15.77 \pm 1.28^{\mathrm{b}}$ & $22.13 \pm 1.69^{\mathrm{b}^{*}}$ \\
AST $(\mathrm{U} / \mathrm{l})$ & $30.10 \pm 0.74$ & $77.69 \pm 12.23^{\mathrm{a}}$ & $32.98 \pm 1.34^{\mathrm{b}}$ & $29.69 \pm 3.35^{\mathrm{b}}$ & $34.30 \pm 2.11^{\mathrm{b}}$ \\
ALP $(\mathrm{U} / \mathrm{l})$ & $25.06 \pm 1.98$ & $48.16 \pm 5.94^{\mathrm{a}}$ & $19.78 \pm 1.80^{\mathrm{b}^{*}}$ & $21.10 \pm 2.23^{\mathrm{b}^{*}}$ & $32.32 \pm 1.23^{\mathrm{b}}$ \\
AP $(\mathrm{U} / \mathrm{l})$ & $10.70 \pm 0.27$ & $20.62 \pm 1.56^{\mathrm{a}}$ & $11.15 \pm 0.38^{\mathrm{b}^{*}}$ & $13.47 \pm 1.27^{\mathrm{b}}$ & $13.10 \pm 0.61^{\mathrm{b}^{*}}$ \\
LDH $(\mathrm{U} / \mathrm{l})$ & $244.24 \pm 16.34$ & $475.95 \pm 24.02^{\mathrm{a}^{*}}$ & $238.81 \pm 9.38^{\mathrm{b}^{*}}$ & $247.98 \pm 13.98^{\mathrm{b}^{*}}$ & $302.66 \pm 20.68^{\mathrm{b}^{*}}$ \\
Glucose $(\mathrm{mg} / \mathrm{dl})$ & $69.19 \pm 2.48$ & $130.96 \pm 10.40^{\mathrm{a}^{*}}$ & $63.86 \pm 06.96^{\mathrm{b}^{*}}$ & $64.61 \pm 03.10^{\mathrm{b}^{*}}$ & $71.16 \pm 0.59^{\mathrm{b}^{*}}$ \\
Total Protein $(\mathrm{g} / \mathrm{dl})$ & $4.10 \pm 0.15$ & $5.82 \pm 0.41^{\mathrm{a}^{*}}$ & $3.94 \pm 0.23^{\mathrm{b}}$ & $3.94 \pm 0.21^{\mathrm{b}}$ & $4.02 \pm 0.24^{\mathrm{b}}$ \\
Albumin $(\mathrm{g} / \mathrm{dl})$ & $3.04 \pm 0.06$ & $3.61 \pm 0.09^{\mathrm{a}^{*}}$ & $3.18 \pm 0.07^{\mathrm{b}}$ & $3.13 \pm 0.078^{\mathrm{b}}$ & $3.23 \pm 0.07^{\mathrm{b}}$ \\
Creatinine $(\mathrm{mg} / \mathrm{dl})$ & $0.88 \pm 0.04$ & $1.70 \pm 0.13^{\mathrm{a}^{*}}$ & $0.95 \pm 0.03^{\mathrm{b}^{*}}$ & $1.01 \pm 0.046^{\mathrm{b}^{*}}$ & $1.04 \pm 0.08^{\mathrm{b}^{*}}$ \\
Urea $(\mathrm{mg} / \mathrm{dl})$ & $24.95 \pm 1.75$ & $50.83 \pm 2.29^{\mathrm{a}^{*}}$ & $29.57 \pm 1.27^{\mathrm{b}^{*}}$ & $23.75 \pm 1.92^{\mathrm{b}^{*}}$ & $28.26 \pm 2.03^{\mathrm{b}^{*}}$ \\
Uric acid $(\mathrm{mg} / \mathrm{dl})$ & $1.58 \pm 0.16$ & $5.68 \pm 0.40^{\mathrm{a}^{*}}$ & $2.16 \pm 0.23^{\mathrm{b}^{*}}$ & $1.59 \pm 0.10^{\mathrm{b}^{*}}$ & $1.70 \pm 0.28^{\mathrm{b}^{*}}$ \\
Cholesterol $(\mathrm{mg} / \mathrm{dl})$ & $39.70 \pm 2.36$ & $82.69 \pm 3.44^{\mathrm{a}^{*}}$ & $43.77 \pm 1.47^{\mathrm{b}^{*}}$ & $42.77 \pm 2.89^{\mathrm{b}}$ & $51.34 \pm 0.43^{\mathrm{b}}$ \\
Triglycerides $(\mathrm{mg} / \mathrm{dl})$ & $38.49 \pm 2.18$ & $90.28 \pm 1.35^{\mathrm{a}^{*}}$ & $40.97 \pm 2.70^{\mathrm{b}^{*}}$ & $41.89 \pm 0.85^{\mathrm{b}^{*}}$ & $50.65 \pm 1.03^{\mathrm{b}^{*}}$ \\
\hline
\end{tabular}

Significance $\left({ }^{(}\right)$: relative to the control group. Significance $\left({ }^{b}\right)$ : relative to the $\mathrm{AlC1}_{3}$ chloride group Significance: $P<0.05$, highly significance $\left(^{*}\right): P<0.001$ 
A

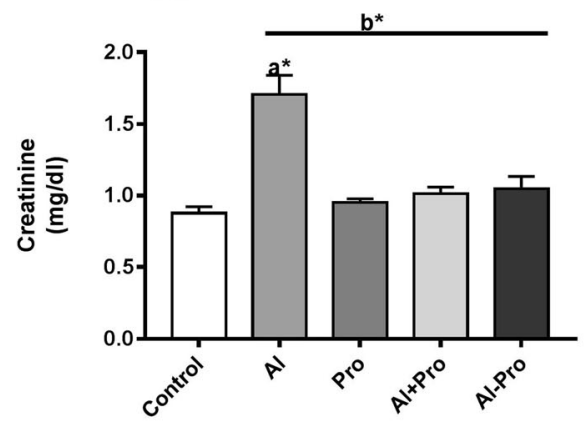

C

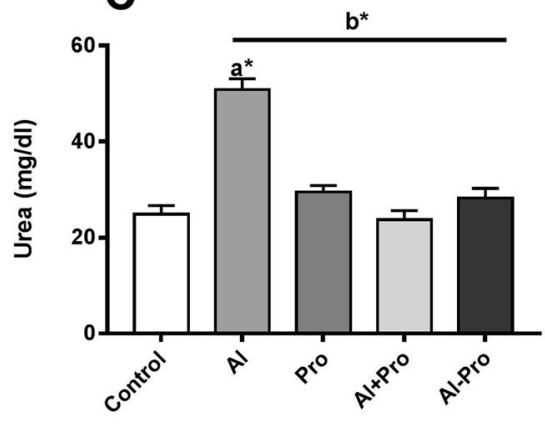

E

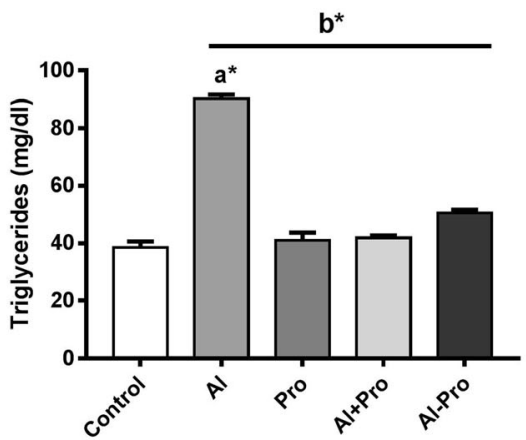

B

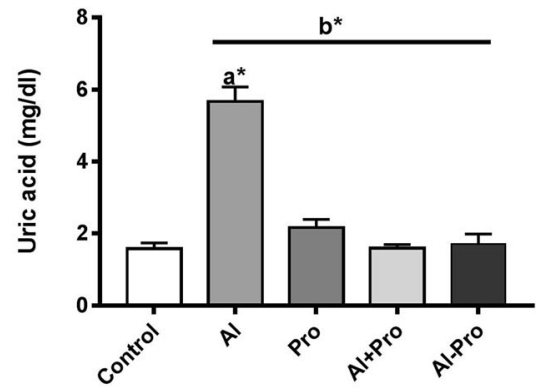

D

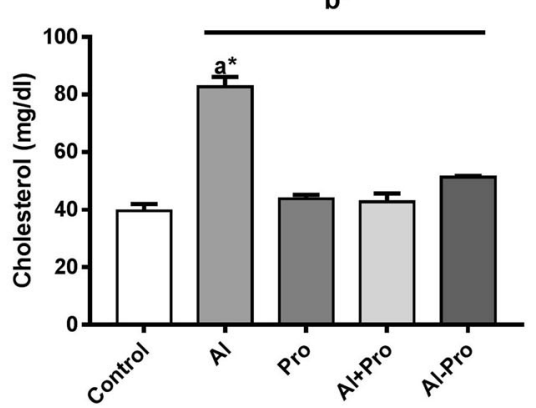

Fig. 1 Effect of propolis for two months on the plasma level of alanine aminotransferase (ALT) (A), aspartate aminotransferase (AST) (B), plasma alkaline phosphatase (ALP) $(\mathbf{C})$, acid phosphatase (AP) (D), and lactate dehydrogenase (LDH) (E) of rats treated with AICl3. Significance (a): relative to the control group. Significance (b): relative to the AlC13 group. Significance: $P<0.05$, highly significance $\left(^{*}\right): P<0.001$

Also, the treatment with $\mathrm{AlCl}_{3}$ led to a highly significant increase $(P<0.001)$ on the plasma level of glucose and albumin while it led to a significant increase $(P<$ $0.05)$ on the plasma level of total protein relative to that of the control. Propolis, $\mathrm{AlCl}_{3}$ combined with propolis, and the administration of $\mathrm{AlCl}_{3}$ for 1 month followed by administration of $\mathrm{AlCl}_{3}$ combined with propolis for another month had non-significant effect $(P>0.05)$ on the plasma level of glucose, total proteins, and albumin as compared to control. In comparison with the effect of
$\mathrm{AlCl}_{3}$, propolis, $\mathrm{AlCl}_{3}$ combined with propolis, and administration of $\mathrm{AlCl}_{3}$ for 1 month followed by administration of $\mathrm{AlCl}_{3}$ combined with propolis for another month led to a highly significant decrease $(P<0.001)$ in the plasma level of glucose and a significant decrease $(P$ $<0.05)$ in the level of plasma total protein and plasma albumin (Table 1, Fig. 2).

Table 1 showed that $\mathrm{AlCl}_{3}$ treatment led to a highly significant increase $(P<0.001)$ in the plasma level of creatinine, urea, and uric acid relative to that of the 


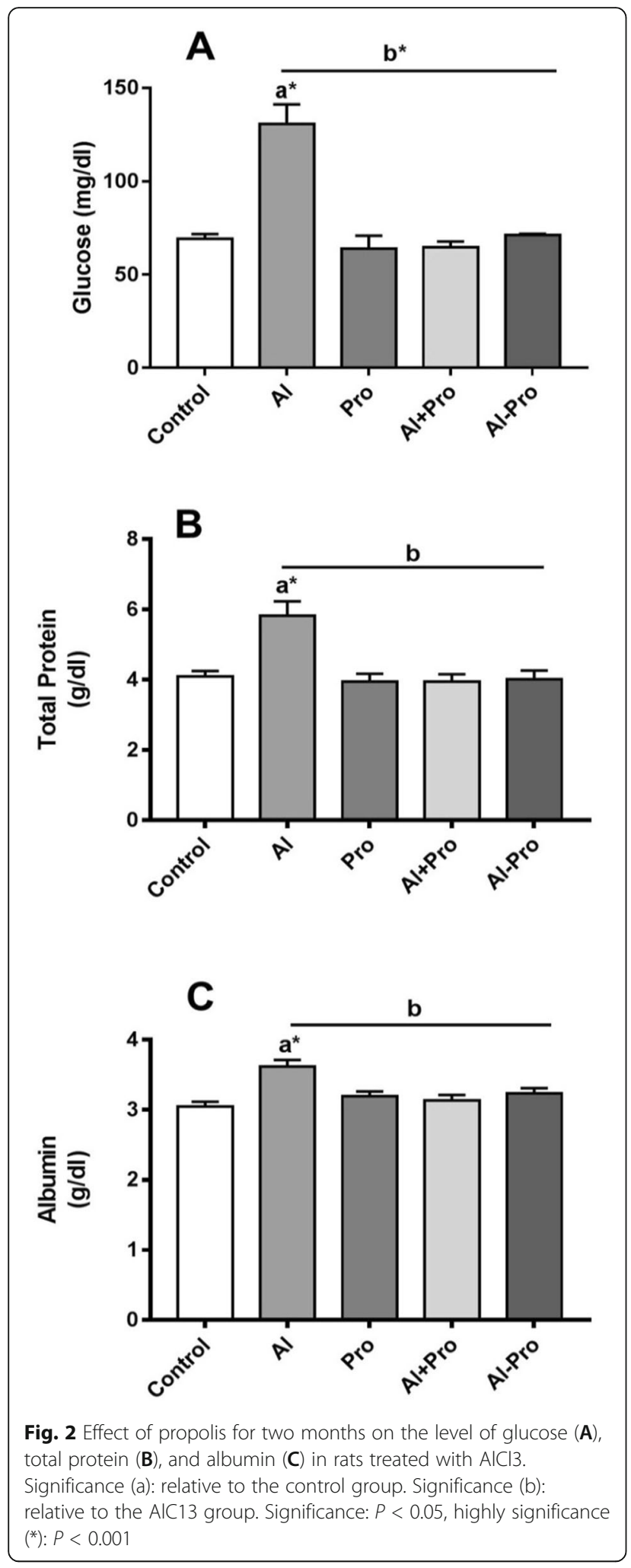

control, whereas propolis, $\mathrm{AlCl}_{3}$ combined with propolis and the administration of $\mathrm{AlCl}_{3}$ for one month followed by administration of $\mathrm{AlCl}_{3}$ combined with propolis for another month had non-significant effect $(P>0.05)$ on the plasma level of creatinine, urea, and uric acid as compared to control. In comparison with the effect of $\mathrm{AlCl}_{3}$ on the plasma level of creatinine, urea and uric acid, the propolis, $\mathrm{AlCl}_{3}$ combined with propolis and administration of $\mathrm{AlCl}_{3}$ for one month followed by administration of $\mathrm{AlCl}_{3}$ combined with propolis for another month led to a highly significant decrease $(P<$ 0.001 ) in the plasma level of creatinine, urea and uric acid (Table 1, Fig. 3).

The $\mathrm{AlCl}_{3}$ administration led to a highly significant increase $(P<0.001)$ in the plasma level of cholesterol and triglycerides, relative to that of control. Propolis and $\mathrm{AlCl}_{3}$ combined with propolis led to a non-significant effect $(P>0.05)$ on the plasma level of cholesterol and triglycerides as compared with that of control, while the administration of $\mathrm{AlCl}_{3}$ for 1 month followed by administration of $\mathrm{AlCl}_{3}$ combined with propolis for another month had a highly significant increase $(P<0.001)$ on the plasma level of cholesterol and triglycerides as compared with that of control (Table 1, Fig. 3). In comparison with the effect of $\mathrm{AlCl}_{3}$ on the level of plasma cholesterol and triglycerides, propolis, $\mathrm{AlCl}_{3}$ combined with propolis, and administration of $\mathrm{AlCl}_{3}$ for 1 month followed by administration of $\mathrm{AlCl}_{3}$ combined with propolis for another month led to a highly significant decrease $(P<0.001)$ in the plasma level of cholesterol and triglycerides as compared to control (Table 1, Fig. $3)$.

\section{Histological results \\ Liver}

Histological examination of the liver sections of different animal groups obtained after 2 months of treatments is given in Fig. 4. The control liver tissue is shown in Fig. 4a. It consists of liver cells arranged in cords that interspersed with sinusoids. In the $\mathrm{AlCl}_{3}$ treated group, the liver tissue shows severe vacuolation with increased inflammatory infiltrated cells among the sinusoids and necrosis of cells with cell nuclei pyknosis (Fig. 4b), as compared to that of the control tissue. No such vacuolation or massive inflammatory cells were detected in either the propolis-treated group (Fig. 4c) or those received $\mathrm{AlCl}_{3}$ combined with propolis (Fig. 4d). The role of propolis in $\mathrm{AlCl}_{3}$ detoxicating efficiency is obvious on comparing the tissue of the liver in the $\mathrm{AlCl}_{3}$-treated group for 1 month followed by $\mathrm{AlCl}_{3}$ combined with propolis for another month with that of $\mathrm{AlCl}_{3}$ combined with propolis (Fig. 4e). However, in both groups nuclear pyknosis is obvious regardless 
A

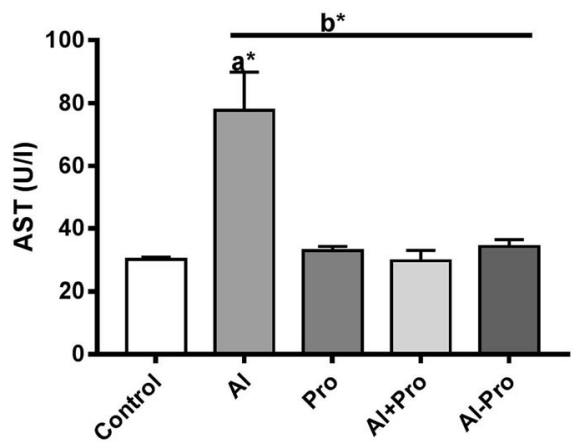

C

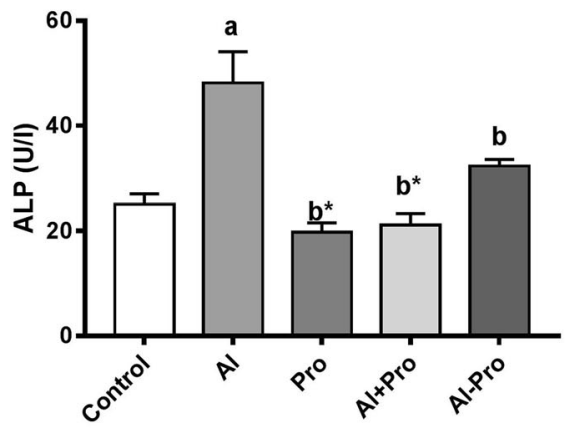

E

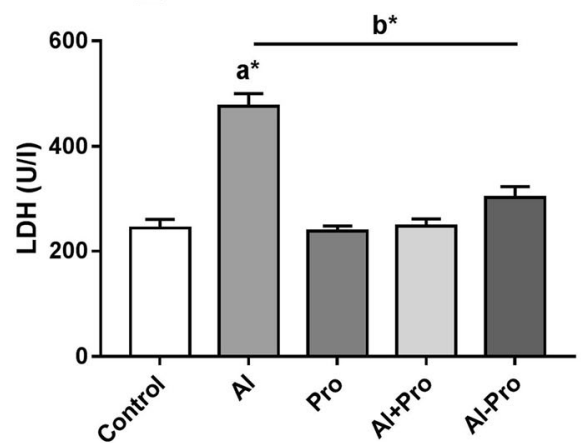

B

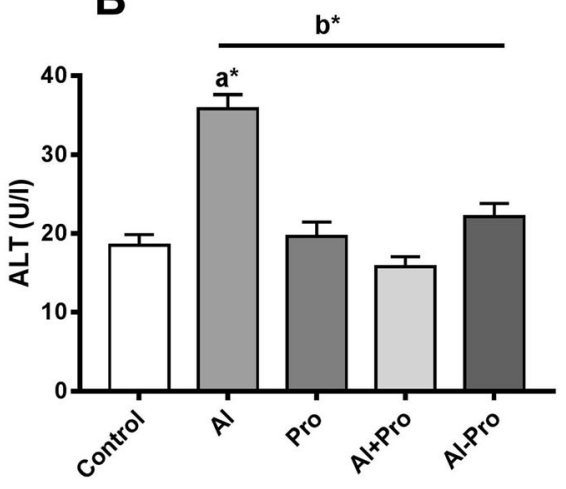

D

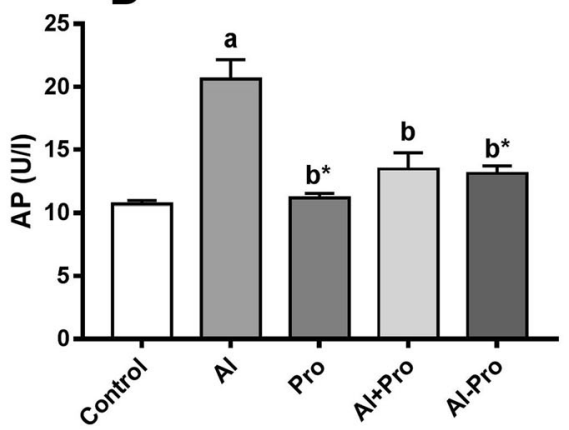

Fig. 3 Effect of propolis for two months on the plasma level of creatinine (A), uric acid (B), urea (C), cholesterol (D), and triglycerides (E) in rats treated with $\mathrm{AICl}$ 3. Significance (a): relative to the control group. Significance (b): relative to the AIC13 group. Significance: $P<0.05$, highly significance $\left(^{*}\right): P<0.001$

the recovered cell degeneration and inflammatory infiltration observed in $\mathrm{AlCl}_{3}$-treated group only.

\section{Kidney}

Histological examination of the kidney sections of different animal groups obtained after 2 months of treatments is given in Fig. 5. The control kidney tissue is shown in Fig. 5a. It consists of well-developed glomeruli and tubules. Examination of the kidney sections from rats treated with $\mathrm{AlCl}_{3}$ revealed a severe histological damage (Fig. 5b), as compared to that of the control. These changes were mainly confined to shrinkage in glomeruli and infiltration with intensive inflammatory cells. No such shrinkage of glomeruli or intensive inflammatory cells was detected in either the propolis-treated animals (Fig. 5c) or those received aluminum chloride combined with propolis (Fig. 5d). The group of the animals which was treated with $\mathrm{AlCl}_{3}$ for 1 month followed by administration of $\mathrm{AlCl}_{3}$ combined with propolis for another month indicates the protective role of propolis; there are no pathological changes were detected (Fig. 5e), as compared to that of $\mathrm{AlCl}_{3}$-treated group. 

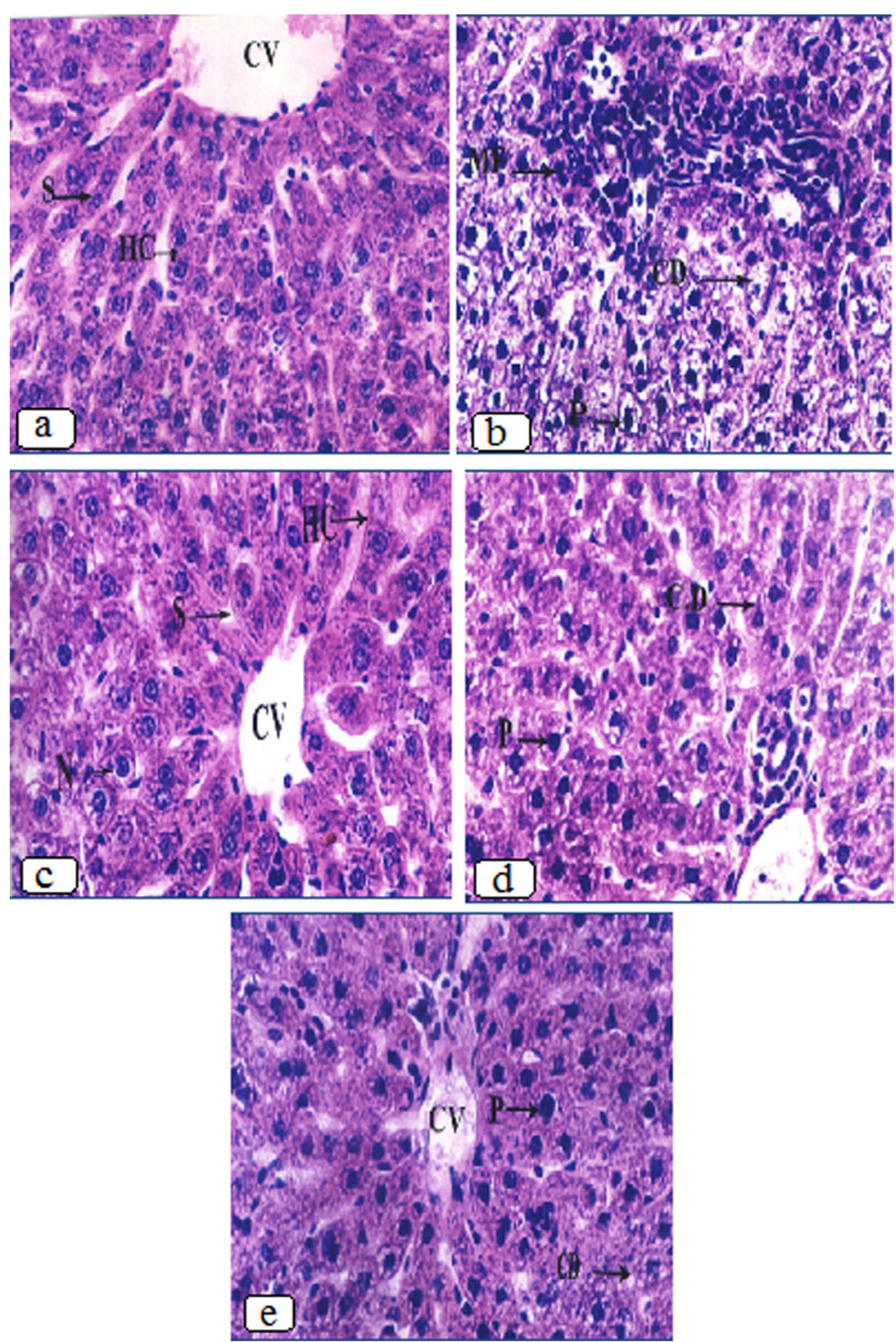

Fig. 4 Photomicrographs of liver sections from control and treated groups, stained with hematoxylin and eosin H\&E (10X). Liver section of control group showing, the hepatic cords (HC), sinusoids (S) that radically arranged around central vein (C.V.) (a). Liver section of AlCl3-treated group showing, massive infiltration (M.F.), cell degeneration (arrow) and nuclear pyknosis (P) (b). Liver section of propolis- treated group showing, normal hepatic cords (HC), sinusoids (S), central vein (C.V.) and normal nuclei (N) (c). Liver section of AlCl3 + propolis treated group showing disappearance of inflammatory infiltration, recovered cell degeneration and little abundance of nuclear pyknosis (P) (d). Liver section of the AlCl3 treatment for one month followed by administration of $\mathrm{AlCl} 3$ combined with propolis for another month group showing improvement of cell degeneration with marked nuclear pyknosis (P) (e)

\section{Discussion}

The present study was carried out to evaluate the protective role of propolis against aluminum toxicity induced biochemical and histological alterations in the liver and kidney of rats. However, it is well known that the plasma enzymes are hepatic health markers, and the alteration in their levels is an indicator of the disturbances in the histological structure of hepatocytes. In the present study, the $\mathrm{AlCl}_{3}$-treated group showed a highly significant increase in the plasma level of enzymes, ALT, AST, ALP, AP, and LDH with marked detectable histopathological alternations in the liver tissues including severe vacuolation with increased inflammatory infiltrated cells among the sinusoids and necrosis of cells with cell nuclei pyknosis. These results are in accordance with other findings showing that the increases in the levels of plasma enzymes are accompanied with histopathological changes in the liver tissue in $\mathrm{AlCl}_{3}$-treated animals (Al-Qayim \& Saadoon, 2013; Bhasin et al., 2014; Bouasla et al., 2014; Cheraghi \& 


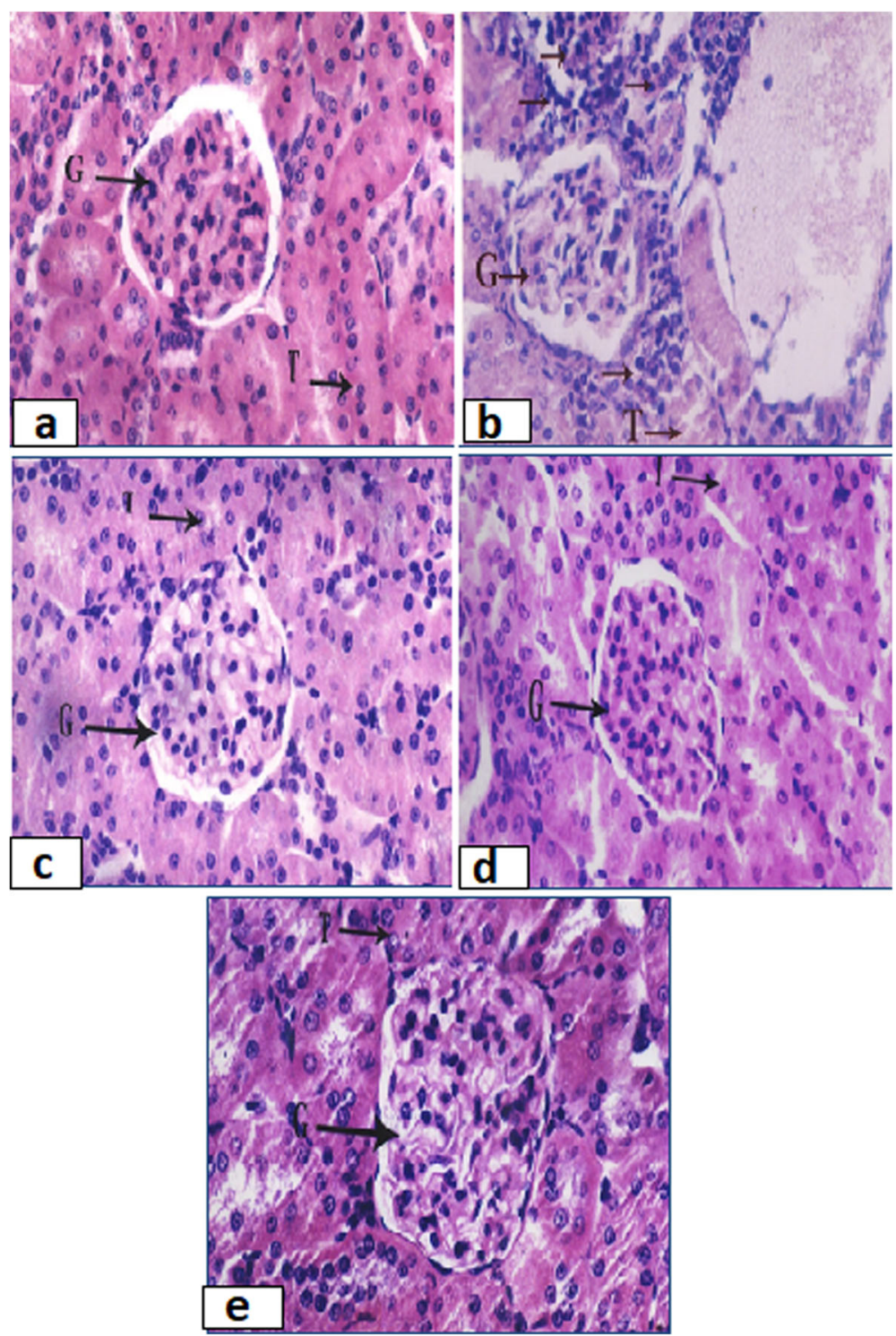

Fig. 5 Photomicrographs of kidney sections from control and treated groups, stained with hematoxylin and eosin H\&E (10X). Kidney section of control group showing normal architecture of kidney tubule (T) and glomerulus (G) (a). Kidney section of AlCl3- treated group showing intensive inflammatory infiltration (arrow) and shrinkage of glomerulus $(\mathrm{G})(\mathbf{b})$. Kidney section of propolis treated group showing normal architecture of kidney tubule (T) and glomerulus (G) (c). Kidney section of AICl3 combined with propolis treated group showing recovered glomerulus (G) and no inflammatory cells were detected as compared to aluminum treated group (d). Kidney section of the AlCl3 treatment for one month followed by administration of AIC13 combined with propolis for another month group showing the protective role of propolis since no glomerular shrinkage or inflammatory cells were detected (e)

Roshanaei, 2019; Geyikoglu, Türkez, Bakir, \& Cicek, 2013; Imam, Khalifa, Hussein, \& Ali, 2016). However, the elevated liver enzymes in the plasma after administration of $\mathrm{AlC}_{3}$ might be due to cellular degeneration and changes in permeability of hepatic cell membranes (Abdel-Wahab, 2012; Hassoun \& Stohs, 1995; Yeh, Lee, Hsieh, \& Hwang, 2009). It had been reported that the accumulation of $\mathrm{AlCl}_{3}$ in the liver tissue is associated with necrosis and degeneration of hepatic tissue to escape of liver enzymes from the injured cells to the plasma (Imam et al., 2016; Yousef, 2004). In addition, histological changes in the liver and the increase of plasma enzyme activities may be due to free radicals production and oxidative stress after $\mathrm{AlCl}_{3}$ administration in the liver tissue (Abdel-Wahab, 2012; Cheraghi \& Roshanaei, 2019).

On the other hand, the administration of propolis, $\mathrm{AlCl}_{3}$ combined with propolis and administration of $\mathrm{AlCl}_{3}$ for 1 month, and administration of $\mathrm{AlCl}_{3}$ combined with propolis for another month showed non- 
significant change on the plasma level of enzymes, ALT, AST, ALP, AP, and LDH with normal liver histological structure, indicating that propolis tended to prevent damage and blocked the enzymes leakage through cellular membranes. These results are in agreements with findings of many studies (Yeh et al., 2009;Wen, Zhao, Nirala, \& Bhadauria, 2012; Al-Qayim \& Saadoon, 2013) who concluded that propolis mostly recovered the action of $\mathrm{AlCl}_{3}$ on the function and structure of the liver. Moreover, the hepatoprotective effect of propolis may be attributed directly to stabilization of redox state in the cells (El-Guendouz et al., 2017; Ibrahim et al., 2019).

The present study revealed that $\mathrm{AlCl}_{3}$ treatment induced a significant increase in the plasma glucose which may indicate disruption in carbohydrate metabolism (Geyikoglu et al., 2013). The hyperglycemia observed in the present study is in accordance with the results of ElDemerdash (2004), Shati and Alamri (2010), and Wen et al. (2012). It was suggested that increase in the plasma glucose level observed in $\mathrm{AlC1}_{3}$-treated group may be due to the inhibition of pancreatic B-cell activity and insufficient insulin secretion (Ibrahim et al., 2019; Yousef, 2004). In contrary, the administration of propolis, $\mathrm{AlCl}_{3}$ combined with propolis, and administration of $\mathrm{AlCl}_{3}$ for 1 month and the administration of $\mathrm{AlCl}_{3}$ combined with propolis for another month showed non-significant change on the level of plasma glucose. These results are in agreements with findings of Wen et al. (2012). In addition, Fuliang et al. (2004) suggested that propolis can control the metabolism of glucose. It has been reported that the potential positive effects of propolis on glucose metabolism in experimental models of diabetic rats (El Araby et al., 2017).

The present study demonstrated that $\mathrm{AlCl}_{3}$ administration induced a significant increase in the plasma level of total protein and albumin. This finding is not in agreement with El-Demerdash (2004) who reported that the decrease of plasma total protein and albumin in $\mathrm{AlCl}_{3}$ treated animals might be related to alterations in synthesis and/or metabolism of protein (Chinoy \& Memon, 2001). On the other hand, the present findings revealed that the propolis and the combined treated groups were similar to that of control in the plasma level of total protein indicating that propolis contains a great amount of flavonoids and proteins, and the propolis interaction with plasma proteins caused conformational changes in the protein (Olinescu, Gidoiu, Safta, \& Popescu, 1982).

The present results showed that the administration of $\mathrm{AlCl}_{3}$ led to a significant increase in the level of plasma creatinine, urea, and uric acid, relative to that of the control group. These biochemical changes were in confirmations with extensive histolopathogica changes including shrinkage in glomeruli and intensive inflammatory cells infiltration in the kidney. Our results are in agreement with Abdel-Wahab (2012) and Imam et al. (2016). They reported that the elevated plasma urea and creatinine levels in $\mathrm{AlCl}_{3}$-treated rats are considered as a substantial marker of renal dysfunction. In addition, Szilagyi et al. (1994) and Geyikoglu et al. (2013) reported that changes in serum urea level may be related to metabolic disturbances. Also, the increase in urea levels in plasma of $\mathrm{AlCl}_{3}$-treated animals may be due to the liver dysfunction as proved by the increase in serum AST, ALT, and ALP activities (Yousef, 2004).

Regarding to the results of cholesterol and triglycerides, the increase in plasma cholesterol and triglycerides is due to loss of membranes integrity (Abdel-Wahab, 2012; Sarin, Gupta, \& Gill, 1997). Also, the increase in plasma triglycerides may be due to hypoactivity of lipoprotein lipase in the blood vessels which break up the triglycerides (Wen et al., 2012). Similarly, Whihelm, Jaeger, Schüll-Cablitz, Hafner, and Idel (1996) reported that $\mathrm{AlCl}_{3}$ exposure can cause $\mathrm{Al}$ accumulation in the liver leading to disturbance of lipid metabolism and an elevation of serum cholesterol.

On the other hand, the effect of propolis or $\mathrm{AlCl}_{3}$ treated with propolis did not show any significant increase in plasma creatinine, urea, and uric acid with normal kidney histological structure in propolis-treated group, while the $\mathrm{AlCl}_{3}$ combined with propolis induced an improvement of the previous histological alternations caused by $\mathrm{AlCl}_{3}$ treatment. With regard to lipid metabolism, plasma concentrations of triglycerides and cholesterol showed no alteration after propolis treatment. Our results are in agreement with Jasprica et al. (2007) who reported normal levels of cholesterol, triglycerides, and uric acid after the propolis supplementation and also are in agreement with Wen et al. (2012) who observed normal levels of urea, uric acid, cholesterol, and triglycerides in combined treatment of HEDTA + propolis-treated animals (Mani, Damasceno, Novelli, Martins, \& Sforcin, 2006).

\section{Conclusion}

The present results demonstrated that the exposure of animals to aluminum is able to induce marked detectable alterations in histological and biochemical characteristics and enzymatic activities. Also, our study demonstrated that the propolis minimized the toxic effects of $\mathrm{AlCl}_{3}$ by reducing the degenerative changes in the liver and kidney tissues and alleviated of biochemical parameters. Consequently, it can be recommended that the exposure to aluminum in our daily life should be reduced, and the intake of diets rich with propolis might be a beneficial method to avoid the aluminum toxicity.

\section{Acknowledgements}

We are thankful to Prof. Dr. Mohamed Farag El-Sayed, Professor Doctor at Department of Zoology, Faculty of Science, Sohag University for the great 
efforts in coordination, planning, and reporting of this study. We are also greatful to Sohag University for supporting this study.

\section{Authors' contributions}

All authors suggested the study and participated in its design and coordination. They carried out both the biochemical analysis and histologica studies and performed the statistical analysis. The authors participated in the manuscript writing and approved the final manuscript.

\section{Funding}

No research funding was available for this study.

\section{Availability of data and materials}

The datasets supporting the conclusions of this article are included within the article, and any explanations are available upon request from the corresponding author.

\section{Ethics approval and consent to participate}

All animal experimental protocols were approved by the Committee of Scientific Ethics at Sohag University and were carried out in accordance with its guidelines and recommendations for animal use.

\section{Consent for publication}

Not applicable

\section{Competing interests}

The authors declare that they have no competing interests.

\section{Received: 30 December 2019 Accepted: 26 May 2020}

\section{Published online: 16 June 2020}

\section{References}

Abdel-Wahab, W. M. (2012). AlCl 3 -induced toxicity and oxidative stress in liver of male rats: Protection by melatonin. Life Sci J, 9(4), 1173-1182

Afsharpour, F., S. Hashemipour, H. Khadem-Haghighian and Y. Koushan (2017): "Effects of Iranian propolis on glucose metabolic changes, inflammatory factors, liver enzymes levels in type 2 diabetic patients: a randomized, double-blind, placebo-controlled, clinical trial." J. Nut Sci\& Diet.

Al-Qayim, A., \& Saadoon, D. (2013). Assessment of the ameliorative role of proplis and malic acid in intestinal and liver functions of aluminum exposed male rats. Int J Sci Nat, 4(3), 552-558.

Andrade, S. F., da Silva Filho, A. A., Cunha, W. R., Nanayakkara, N. D., \& Bastos, J. K. (2008). Antileishmanial, antimalarial and antimicrobial activities of the extract and isolated compounds from Austroplenckia populnea (Celastraceae). Zeitschrift für Naturforschung. Section C, 63(7-8), 497-502.

Bablok, W., Passing, H., Bender, R., \& Schneider, B. (1988). A general regression procedure for method transformation. Application of linear regression procedures for method comparison studies in clinical chemistry, Part III. Clinical Chemistry and Laboratory Medicine, 26(11), 783-790.

Bancroft J. and Gamble M (2008):Theory and practicle of histological techniques, 6th ed Churkhil Livinstone, London, UK:P433.

Banskota, A. H., Nagaoka, T., Sumioka, L. Y., Tezuka, Y., Awale, S., Midorikawa, K.,... Kadota, S. (2002). Antiproliferative activity of the Netherlands propolis and its active principles in cancer cell lines. Journal of Ethnopharmacology, 80(1), 67-73.

Barham, D., \& Trinder, P. (1972). Enzymatic determination of uric acid. Analyst, 97, $142-145$

Bhasin, P., Singla, N., \& Dhawan, D. (2014). Protective role of zinc during aluminum-induced hepatotoxicity. Environmental Toxicology, 29(3), 320-327.

Bouasla, I., Bouasla, A., Boumendjel, A., Messarah, M., Abdennour, C., Boulakoud, M. S., \& El Feki, A. (2014). Nigella sativa oil reduces aluminium chlorideinduced oxidative injury in liver and erythrocytes of rats. Biological Trace Element Research, 162(1-3), 252-261.

Cabaud, P. G., Wróblewski, F., ok, W. t. T. A., \& Ruggiero, V. (1958). Colorimetric measurement of lactic dehydrogenase activity of body fluids. American J. Clin Path, 30(3), 234-236.

Castaldo, S., \& Capasso, F. (2002). Propolis, an old remedy used in modern medicine. Fitoterapia, 73, S1-S6.

Cheraghi, E., \& Roshanaei, K. (2019). The protective effect of curcumin against aluminum chloride-induced oxidative stress and hepatotoxicity in rats. Pharm Biomed Res, 5(1), 6-13.
Chinoy, N., \& Memon, M. (2001). Beneficial effects of some vitamins and calcium on fluoride and aluminium toxicity on gastrocnemius muscle and liver of male mice. Fluoride, 34(1), 21-33.

Cole, N., Sou, P. W., Ngo, A., Tsang, K. H., Severino, J. A., Arun, S. J., ... Reeve, V. E. (2010). Topical 'Sydney' propolis protects against UV-radiation-induced inflammation, lipid peroxidation and immune suppression in mouse skin. International Archives of Allergy and Immunology, 152(2), 87-97.

Doumas, B., \& Biggs, H. (1976). Standard methods of clinical chemistry. New York: Academic Press.

El Araby, B., Ahmed, D. F. I., \& Zahkouk, S. A. (2017). Effect of Foeniculum vulgare and propolis on liver in alloxan diabetic rats. Adv Bioll Res, 11(5), 311-318.

El-Demerdash, F. M. (2004). Antioxidant effect of vitamin E and selenium on lipid peroxidation, enzyme activities and biochemical parameters in rats exposed to aluminium. Journal of Trace Elements in Medicine and Biology, 18(1), 113-121.

El-Guendouz, S., Al-Waili, N., Aazza, S., Elamine, Y., Zizi, S., Al-Waili, T., ... Lyoussi, B. (2017). Antioxidant and diuretic activity of co-administration of Capparis spinosa honey and propolis in comparison to furosemide. Asian Pacific Journal of Tropical Medicine, 10(10), 974-980.

Elmenoufy, G. A. (2012). Bee honey dose-dependently ameliorates lead acetatemediated hepatorenal toxicity in rats. Life Sci J, 9(4), 780-788.

Farooqui, T., \& Farooqui, A. A. (2010). Molecular mechanism underlying the therapeutic activities of propolis: A critical review. Current Nutrition \& Food Science, 6(3), 186-199.

Fuliang, H. U., Hepburn, H. R., Xuan, H., Chen, M., Daya, S., \& Radloff, S. E. (2004). Effects of propolis on blood glucose, blood lipid and free radicals in rats with diabetes mellitus. Pharmacological Research, 104, 147-152.

Geyikoglu, F., Türkez, H., Bakir, T. O., \& Cicek, M. (2013). The genotoxic, hepatotoxic, nephrotoxic, haematotoxic and histopathological effects in rats after aluminium chronic intoxication. Toxicology and Industrial Health, 29(9), 780-791.

Hassoun, E., \& Stohs, S. (1995). Comparative studies on oxidative stress as a mechanism for the fetotoxic of TCDD, endrin and lindane in C57BL/6J and DBA/2J mice. Teratology, 51(3), 186.

Henry, R. J. (1964): "Clinical chemistry, principles and technics." Harper And Row Puplishers, New York. P.181

Hyvarinen, A. AND E. Nikkila (1962). "Specific determination of blood glucose with o toluidine." Clinica Chimica Acta 7: 140-14+

Ibrahim, M. A., Khalifa, A. M., Saleh, A. A., \& Tammam, H. G. (2019). Histopathological and histochemical assessment of monosodium glutamateinduced hepatic toxicity and the amelioration with propolis. Ain Shams Journal of Forensic Med \& Clin Tox, 33, 24-36.

Imam, T. S., Khalifa, H. A., Hussein, M., \& Ali, H. A. (2016). Aluminum-induced oxidative stress and hepato-renal impairment in male albino rats: Possible protective trial with naringenin. Life Sci J., 12, 1s.

Ivanovska, N., Dimov, V., Pavlova, S., Bankova, V., \& Popov, S. (1995). Immunomodulatory action of propolis. $\mathrm{V}$. Anticomplementary activity of a water-soluble derivative. Journal of Ethnopharmacology, 47(3), 135-143.

Jasprica, I., Mornar, A., Debeljak, Ž., Smolčić-Bubalo, A., Medić-Šarić, M., Mayer, L., ... Sobočanec, S. (2007). In vivo study of propolis supplementation effects on antioxidative status and red blood cells. J.Ethnopharm., 110(3), 548-554.

KrasovskiĬ, G., Vasukovich, L., \& Chariev, O. (1979). Experimental study of biological effects of leads and aluminum following oral administration. Environmental Health Perspectives, 30, 47-51.

Kumar, V., Bal, A., \& Gill, K. D. (2009). Susceptibility of mitochondrial superoxide dismutase to aluminium induced oxidative damage. Tox., 255(3), 117-123.

Kutlubay, R., Oğuz, E. O., Güven, C., Can, B., Sinik, Z., \& Tuncay, Ö. L. (2007). Histological and ultrastructural evidence for protective effects on aluminiuminduced kidney damage by intraperitoneal administration of a-Tocopherol. International Journal of Toxicology, 26(2), 95-101.

Machado, B. S., Pulcino, T. N., Silva, A. L., Melo, D. T., Silva, R. G., \& Mendonça, I. G. (2016). Propolis as an alternative in prevention and control of dental cavity. J. Apitherapy, 1(2), 47-50.

Mani, F., Damasceno, H., Novelli, E., Martins, E., \& Sforcin, J. (2006). Propolis: Effect of different concentrations, extracts and intake period on seric biochemical variables. J.Ethnopharm., 105(1-2), 95-98.

Moss, D. W. (1984). Acidic phosphatases. Methods of enzymatic analysis, 4, 93-101.

Newairy, A.-S. A., Salama, A. F., Hussien, H. M., \& Yousef, M. I. (2009). Propolis alleviates aluminium-induced lipid peroxidation and biochemical parameters in male rats. Food and Chemical Toxicology, 47(6), 1093-1098.

Ochmański, W. \& Barabasz, W. (2000). Aluminum--occurrence and toxicity for organisms. Przegląd Lekarski, 57(11), 665-668. 
Olinescu, R., Gidoiu, T., Safta, T., \& Popescu, E. (1982). Biochemical mechanism involved in the pharmacodynamic effect of propolis. Stud Cerret Biochim, 25, 258-264.

Oršolić, N. (2010). A review of propolis antitumor action in vivo and in vitro. J. ApiProduct \& ApiMed Sci, 2(1), 1-20.

Orsolic, N., Sver, L., Terzic, S., \& Basic, I. (2005). Peroral application of water-soluble derivative of propolis (WSDP) and its related polyphenolic compounds and their influence on immunological and antitumour activity. Veterinary Research Communications, 29(7), 575

Patton, C. J., \& Crouch, S. (1977). Spectrophotometric and kinetics investigation of the Berthelot reaction for the determination of ammonia. Analytical Chemistry, 49(3), 464-469.

Peña, R. C. (2008). Propolis standardization: A chemical and biological review. Cien. Inv. Agr. 35 (1): 17-26. Ciencia e Investigación Agraria, 35(1), 11-20.

Reiter, R. J., Tan, D.-X., Terron, M. P., Flores, L. J., \& Czarnocki, Z. (2007). Melatonin and its metabolites: New findings regarding their production and their radical scavenging actions. ACTA BIOCHIMICA POLONICA-ENGLISH EDITION, 54(1), 1.

Reitman, S., \& Frankel, S. (1957). A colorimetric method for the determination of serum glutamic oxalacetic and glutamic pyruvic transaminases. American J. Clin.L Path, 28(1), 56-63.

Rizk, S. M., Zaki, H. F., \& Mina, M. A. (2014). Propolis attenuates doxorubicininduced testicular toxicity in rats. Food and Chemical Toxicology, 67, 176-186.

Sarin, S., Gupta, V., \& Gill, K. D. (1997). Alterations in lipid composition and neuronal injury in primates following chronic aluminium exposure. Biological Trace Element Research, 59(1-3), 133-143.

Shati, A. A. \& Alamri, S. A. (2010). Role of saffron (Crocus sativus L) and honey syrup on aluminum-induced hepatotoxicity. Saudi Medical Journal, 31(10), 1106-1113.

Simões, L. M. C., Gregório, L. E., Da Silva Filho, A., De Souza, M., Azzolini, A. E. C. S., Bastos, J. K., \& Lucisano-Valim, Y. M. (2004). Effect of Brazilian green propolis on the production of reactive oxygen species by stimulated neutrophils. J. ethnopharm, 94(1), 59-65.

Stevanović, I. D., Jovanović, M. D., Jelenković, A., Čolić, M., Stojanović, I., \& Ninković, M. (2009). Effects of L-NAME, a non-specific nitric oxide synthase inhibitor, on $\mathrm{AlCl} 3$-induced toxicity in the rat forebrain cortex. Journal of Veterinary Science, 10(1), 15-22.

Szilagyi, M., Bokori, J., Fekete, S., Vetesi, F., Albert, M., \& Kadar, I. (1994). Effects of long-term aluminium exposure on certain serum constituents in broiler chickens. European J. Clin.L Chem.\& Clinl Biochem, 32(6), 485-486.

Turgut, S., Bor-Kucukatay, M., Emmungil, G., Atsak, P., \& Turgut, G. (2007). The effects of low dose aluminum on hemorheological and hematological parameters in rats. Archives of Toxicology, 81(1), 11-17.

TÜRKEZ, H., GEYIKOĞLU, F., \& Colak, S. (2011). The protective effect of boric acid on aluminum-induced hepatotoxicity and genotoxicity in rats. Turkish Journal of Biology, 35(3), 293-301

Wagh, V. D. (2013):"Propolis: A wonder bees product and its pharmacological potentials." Adv. in pharm.I sci. 2013

Watanabe, M. A. E., Amarante, M. K., Conti, B. J., \& Sforcin, J. M. (2011). Cytotoxic constituents of propolis inducing anticancer effects: A review. The Journal of Pharmacy and Pharmacology, 63(11), 1378-1386.

Watson, D. (1960). A simple method for the determination of serum cholesterol. Clinica Chimica Acta, 5(5), 637-643.

Weissman, M., Pileggi, V., Henry, R., Cannon, D., \& Winkelman, J. (1974). Clinical chemistry: principles and techniques. Hagerstown, MD: Harper and Row Publishers.

Wen, Y.-F., Zhao, J.-Q., Nirala, S. K., \& Bhadauria, M. (2012). Aluminum-induced toxicity and its response to combined treatment of HEDTA and propolis in rats. Polish Journal of Environmental Studies, 21(5).

Whihelm, M., Jaeger, D. E., Schüll-Cablitz, H., Hafner, D., \& Idel, H. (1996). Hepatic clearance and retention of aluminium: Studies in the isolated perfused rat liver. Toxicology Letters, 89(3), 257-263.

Yeh, Y.-H., Lee, Y.-T., Hsieh, H.-S., \& Hwang, D.-F. (2009). Effect of taurine on toxicity of aluminum in rats. e-SPEN, the European e-J. Clin. Nut. \& Metabol, 4(4), e187-e192.

Yousef, M. I. (2004). Aluminium-induced changes in hemato-biochemical parameters, lipid peroxidation and enzyme activities of male rabbits: Protective role of ascorbic acid. Tox., 199(1), 47-57.

\section{Publisher's Note}

Springer Nature remains neutral with regard to jurisdictional claims in published maps and institutional affiliations.

\section{Submit your manuscript to a SpringerOpen ${ }^{\circ}$ journal and benefit from:}

- Convenient online submission

- Rigorous peer review

- Open access: articles freely available online

- High visibility within the field

- Retaining the copyright to your article

Submit your next manuscript at $\boldsymbol{\nabla}$ springeropen.com 